\title{
Diagnosis on the marketing and technological strategies used by MSMEs
}

\section{Diagnóstico de las estrategias tecnológicas y de marketing utilizadas por las MIPYMES}

\author{
ARMANDO-RODRÍGUEZ, Sergio*†, GARCÍA-BAHENA, María Gabriela, HERNÁNDEZ-VÉLEZ, \\ Mónica and WALDO-CAAMAÑO, José David
}

Universidad Tecnológica de Nezahualcóyotl

ID $1^{\text {st }}$ Author: Sergio Armando-Rodríguez / ORC ID: 0000-0001-5623-0188

ID $1^{\text {st }}$ Coauthor: María Gabriela García-Bahena / ORC ID: 0000-0002-8141-5894

ID $2^{\text {nd }}$ Coauthor: Mónica Hernández-Vélez / ORC ID: 0000-0003-4003-6115

ID $3^{\text {rd }}$ Coauthor: José David Waldo-Caamaño / ORC ID: 0000-0002-6138-9617

DOI: $10.35429 / J B A B .2019 .4 .3 .15 .21$

Received March 22, 2019; Accepted June 30, 2019

\begin{abstract}
Commercial and technological dynamics have brought great changes to companies, and MSMEs are no exception; currently, the market has more information about the diversity of satisfiers it can choose to cover its needs, about the companies that produce and market them, and about the different actions they carry out and implement; however, in this scenario, MSMEs are at a disadvantage, mainly due to the lack of resources and experience. In an increasingly competitive commercial world, a constant concern of MSMEs is the form and means that are adequate, sufficient and necessary to ensure that the services and products they offer reach consumers. The new trends in the business world make it necessary to understand and adapt to two factors: a globalized and therefore technologized world; and the change of paradigms in how to perceive the recipient of services and products: client, consumer, user... human being? The present work aims to identify and diagnose the most pressing shortcomings in the areas of technology and marketing presented by companies, through a quantitative research applied to 137 MSMEs in the main municipalities which have formal links with the Technological University of Nezahualcóyotl, supported by a questionnaire for data collection. The results obtained will serve as a basis for proposing marketing and commercial communication strategies, making use of the TIICC; for the case of a generic form, that adapted to the reality and specific needs, each company could carry out, and consequently resolve part of their needs, increase their sales and develop their business.
\end{abstract}

\begin{abstract}
Resumen
La dinámica comercial y tecnológica ha traído grandes cambios a las empresas, y las MIPYME no son una excepción; actualmente, el mercado tiene más información sobre la diversidad de satisfactores que puede elegir para cubrir sus necesidades, sobre las empresas que los producen y comercializan, y sobre las diferentes acciones que llevan a cabo e implementan; sin embargo, en este escenario, las MIPYMES están en desventaja, principalmente debido a la falta de recursos y experiencia. En un mundo comercial cada vez más competitivo, una preocupación constante de las MIPYMES es la forma y los medios que son adecuados, suficientes y necesarios para garantizar que los servicios y productos que ofrecen lleguen a los consumidores. Las nuevas tendencias en el mundo de los negocios hacen que sea necesario comprender y adaptarse a dos factores: un mundo globalizado y, por lo tanto, tecnologizado; y el cambio de paradigmas en cómo percibir al destinatario de servicios y productos: cliente, consumidor, usuario ... ¿ iser humano? El presente trabajo tiene como objetivo identificar y diagnosticar las deficiencias más apremiantes en las áreas de tecnología y marketing presentadas por las empresas, a través de una investigación cuantitativa aplicada a 137 MIPYME en los principales municipios que tienen vínculos formales con la Universidad Tecnológica de Nezahualcóyotl, respaldada por un cuestionario. para la recogida de datos Los resultados obtenidos servirán de base para proponer estrategias de marketing y comunicación comercial, haciendo uso del TIICC; Para el caso de una forma genérica, que se adapta a la realidad y a las necesidades específicas, cada empresa podría llevar a cabo y, en consecuencia, resolver parte de sus necesidades, aumentar sus ventas y desarrollar su negocio.
\end{abstract}

Citation: ARMANDO-RODRÍGUEZ, Sergio, GARCÍA-BAHENA, María Gabriela, HERNÁNDEZ-VÉLEZ, Mónica and WALDO-CAAMAÑO, José David. Diagnosis on the marketing and technological strategies used by MSMEs. JournalBusiness Administration -Marketing; Accounting. 2019. 3-4: 15-21

\footnotetext{
* Correspondence to Author (email: armando.rodriguezse@utn.edu.mx)

$\uparrow$ Researcher contributing as first author.
} 


\section{Introduction}

The growing need of companies of all sizes to maintain and consolidate themselves in such a competitive and globalized market has led to the recognition, even by those who put up resistance, of the transcendental role of the implementation of marketing strategies and the use of technology in commercial activities, which contribute to achieving a better position in the market. In this sense, marketing offers answers to the questions presented by micro and small organizations regarding their marketing, technological, advertising and promotion processes for goods and services.

Considering the above, this document mainly integrates the results of a diagnosis made to MSMEs in a part of the eastern region of the State of Mexico, which allows visualizing the needs in terms of marketing and use of technology in commercial activity, so we integrated an initial analysis of the situation in the area, the methodological development to obtain substantive information, the results of this research and finally the conclusions and suggestions derived from the findings.

\section{Methodology}

\section{Problem Statement}

The municipality of Nezahualcóyotl was created 55 years ago, the 125th in the genesis of the State of Mexico, and is now one of the most developed municipalities economically, culturally and socially. Less than 30 year ago, it was considered a dormant region, but today it possesses great development concerning urban, educational and commercial infrastructure. In addition, "40 years ago (...) 90 percent of the Economically Active Population (EAP) of Nezahualcóyotl moved to other nodes to work, particularly to Mexico City, and only 10 percent stayed to work in the commercial and service sector of the municipality. Today the figure has changed significantly, as only 30 percent of the EAP leaves, while the other 70 percent is employed in the commercial and service sector - the strongest sector in the municipality". (Linares, 2014). From then, the economic development in the municipality is based, above all, on the provision of goods and services; moreover, it already has an industrial corridor that houses an average of one hundred manufacturing and processing companies.
It also has three shopping centers in the central-eastern area, and two more in the northern area. They house companies with international presence, as well as micro, small and medium enterprises, some of which have benefited from the academic and business projects that the Technological University of Nezahualcóyotl (UTN) carries out as part of its academic and networking activities.

Due to the previous tasks, researchers have observed the impressive lack of business vision, marketing and commercial communication strategies. Many projects implemented in companies in the municipality are evidence of this. In this context, and as a consequence of the needs that MSMEs have shown, a group of professors grouped in the New Technologies and MSMEs Academic Body, took on the task of knowing what resources from marketing and new technologies are used by the business sector of the municipality and the region; and to know the needs of commercial communication, to propose a training strategy aimed at companies in order to present the benefits of having a business plan with defined strategies of marketing and communication using, above all, the advantages offered by the TTIICC.

\section{Frame of Reference}

According to Anzola (1996) "Small and medium enterprises are engaged in commercial activity. It is also well known that companies dedicated to the processing of products market them, discarding as much as possible the intermediaries and achieving a more direct relationship between producer and consumer. The small and medium enterprises are dedicated to retail sales, even though this is one of the most competitive sectors and leaves less profit margin; but considering that this type of small enterprise becomes relatively easy and that the risks of its operations are lower, it is attractive."

In Mexico "94.3 percent of new establishments are micro enterprises, according to data from the National Institute of Geography and Statistics (INEGI). Such is the importance of micro businesses that offer 72 percent of jobs in the nation." (Garibay, 2016) 
For this reason, it is worth distinguishing between a micro and a small enterprise. The small enterprise has a minimal formal structure, makes use of techniques, strategies and technological resources, there is a standardized form of organization; the number of employees ranges from 11 to 50; above all, there is a clear idea of the business thinking, mission and vision.

The micro, on the other hand, is formed by between two and 10 people, according to the number of activities they perform. Examples of these are the food stalls or the little shops on the corner of the street. They usually market or provide services in the tertiary sector, generating a variable turnover per year, but with sufficient income to cover their costs, even with an interesting profit margin." (Fernández, 2007)

Most of the micro and small enterprises are part of a family history, which in the case of the municipality, comes from before its creation as such, and are revitalized with the generations, although, unfortunately, by this selfmanagement genesis, suffer from a business thinking, mission and vision. This greatly inhibits the incorporation of resources, technologies and market strategies that allow them to grow, and in fact to compete not only with the micro and small enterpreises, but perhaps to bet on a development and growth that allows them to be placed in higher markets.

\section{General Objective}

To detect the market and technological needs of MSMEs in the municipality of Nezahualcóyotl through market research to be carried out during the months of July and August.

\section{Research Design}

An exploratory research was developed with a quantitative approach that allows, through a quantifiable analysis, to know the characteristics of MSMEs and their most important technological and commercial gaps for their commercial development in the market.

\section{Collection Method and Instrument}

A closed-ended instrument (questionnaire) was designed to obtain the necessary information on the marketing and commercial communication resources used and/or needed by MSMEs in Nezahualcóyotl.
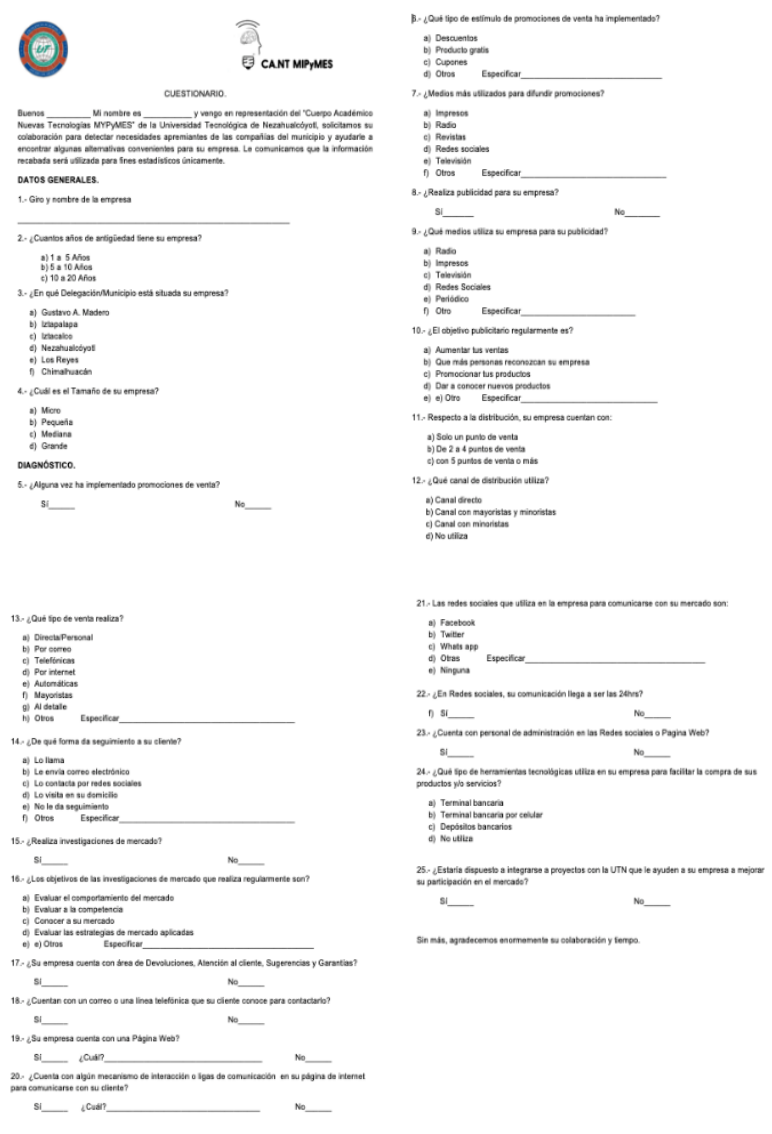

\section{Universe and Sample}

We worked with a finite population of 39,630 companies in the municipality of Nezahualcóyotl (INEGI, 2019) and using the finite population formula we obtained a finite sample of 137 elements, managing a confidence level of $90 \%$ and a margin of error of $7 \%$.

\section{Data Collection}

Data collection was carried out at the Nezahualcóyotl Technological University in a Networking session held on July 18, 2019, and through direct surveys in the area of influence, from July 22 to 26, 2019, with the collaboration of students from the Marketing Division.

\section{Data Analysis}

The data analysis was statistical, and the information obtained was tabulated and graphed, adding the respective analysis and interpretation of results. 


\section{Graph presentation by question}

\begin{tabular}{|c|c|}
\hline Question & Analysis \\
\hline $\begin{array}{l}\text { ¿Cuántos años de antiguedad tiene } \\
\text { su empresa? }\end{array}$ & $\begin{array}{l}\text { The data offered in the } \\
\text { graph are clear, regarding } \\
\text { the short life of most of the } \\
\text { companies; moreover: they } \\
\text { reflect a constant birth and } \\
\text { growth of companies, that } \\
\text { is, the municipality is fertile } \\
\text { land for investment and } \\
\text { creation of new businesses. }\end{array}$ \\
\hline $\begin{array}{l}\text { ¿En que municipio está situada su empresa? } \\
\text { Area del grático }\end{array}$ & $\begin{array}{l}\text { At the regional level (east of } \\
\text { the State of Mexico) } \\
\text { Nezahualcóyotl is the } \\
\text { municipality with the } \\
\text { largest number of } \\
\text { companies, which means a } \\
\text { higher economic } \\
\text { development in the regional } \\
\text { context. }\end{array}$ \\
\hline $\begin{array}{l}\text { Grande ¿Cuál es el tamaño de su } \\
\text { empresa? }\end{array}$ & $\begin{array}{l}\text { Although the graph presents } \\
\text { a mixture of sizes, micro } \\
\text { and small predominate, } \\
\text { which is evident from the } \\
\text { type of services and goods } \\
\text { offered; a simple tour of the } \\
\text { streets of the municipality } \\
\text { shows this trend. }\end{array}$ \\
\hline 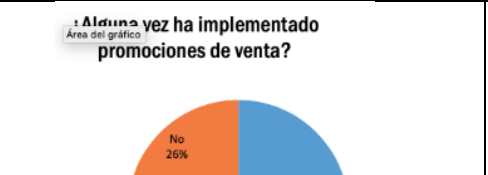 & $\begin{array}{l}\text { Beyond the size of the } \\
\text { company, what is certain is } \\
\text { that an important majority } \\
\text { carries out promotional } \\
\text { activities for the goods and } \\
\text { services it offers. }\end{array}$ \\
\hline 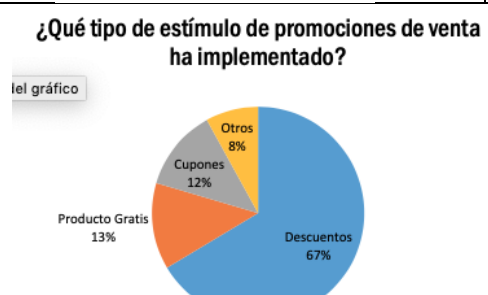 & $\begin{array}{l}\text { Regardless of the great } \\
\text { diversity of promotional } \\
\text { tools, the graphics reflect } \\
\text { that discounts are the most } \\
\text { used form to promote } \\
\text { themselves; the companies } \\
\text { have found in the coupons } \\
\text { and the free delivery of } \\
\text { products a form to become } \\
\text { tangible for the consumer. }\end{array}$ \\
\hline $\begin{array}{l}\text { ¿Merinc más utilizados para difundir } \\
\text { Area del gráfico } \\
\text { promociones? } \\
\substack{\text { Televisión } \\
1 \%} \begin{array}{c}\text { Otros } \\
13 \%\end{array} \\
\end{array}$ & $\begin{array}{l}\text { The mainly used } \\
\text { commercial communication } \\
\text { resources are the delivery of } \\
\text { printed pieces, above social } \\
\text { networks. Other forms are } \\
\text { practically ruled out, such as } \\
\mathrm{TV} \text {, radio and magazines, } \\
\text { because of the low number } \\
\text { of users and the cost of } \\
\text { publication. }\end{array}$ \\
\hline $\begin{array}{l}\text { ¿Realiza Puhlicidad para su empresa? } \\
\text { Area del gráfico }\end{array}$ & $\begin{array}{l}\text { More than half of the } \\
\text { companies implement } \\
\text { advertising activities; what } \\
\text { is missing now is a review } \\
\text { of whether such strategies } \\
\text { are in line with the market, } \\
\text { the product and the } \\
\text { opportunity. The rest will } \\
\text { have to be convinced, via } \\
\text { training and consultancy, of } \\
\text { the benefits of this } \\
\text { substantive element of } \\
\text { promotion. }\end{array}$ \\
\hline
\end{tabular}

June, 2019 Vol.3 No.4 15-21

\begin{tabular}{|c|c|}
\hline $\begin{array}{l}\text { ¿Qué medios utiliza su empresa para su } \\
\text { publicidad? }\end{array}$ & $\begin{array}{l}\text { The distribution of printed } \\
\text { pieces continues to be the } \\
\text { advertising strategy most } \\
\text { used by companies in this } \\
\text { area of the State of Mexico, } \\
\text { just above the social } \\
\text { networks, which is good } \\
\text { because they are finding in } \\
\text { the technological resources } \\
\text { perhaps a better way to } \\
\text { reach consumers. } \\
\text { Traditional media such as } \\
\text { radio, TV and printed } \\
\text { inserts are practically } \\
\text { nullified. }\end{array}$ \\
\hline 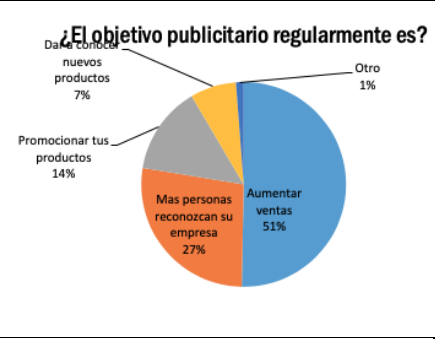 & $\begin{array}{l}\text { Increasing sales is for most } \\
\text { companies the main } \\
\text { objective of their } \\
\text { advertising action, whatever } \\
\text { it is; an important } \\
\text { percentage for others is to } \\
\text { achieve positioning, and to } \\
\text { make new products known. } \\
\text { In all three cases, it is } \\
\text { necessary to point out how } \\
\text { right the companies' } \\
\text { purpose is. }\end{array}$ \\
\hline 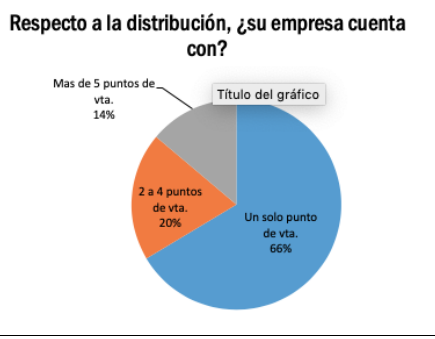 & $\begin{array}{l}\text { As micro and small } \\
\text { enterprises, it is understood } \\
\text { that most of them only have } \\
\text { one point of sale, where all } \\
\text { the activities -commercial } \\
\text { and administrative- are } \\
\text { regularly carried out, which } \\
\text { can be a limitation for the } \\
\text { growth of the organization. } \\
\text { The rest, although it has up } \\
\text { to five points of sale, is not } \\
\text { very representative. }\end{array}$ \\
\hline $\begin{array}{l}\text { ¿Qué canal de distribución utiliza? } \\
{ }_{3 \%}^{\text {Canal con min. }} \underset{\substack{\text { Área del gráfico } \\
\text { Notiliza } \\
15 \%}}{4}\end{array}$ & $\begin{array}{l}\text { In the same way, the most } \\
\text { efficient form of } \\
\text { distribution is through direct } \\
\text { channels and retail. Less } \\
\text { than a quarter offer } \\
\text { wholesale and retail } \\
\text { channels, which can offer an } \\
\text { opportunity to involve } \\
\text { technology. }\end{array}$ \\
\hline $\begin{array}{l}\text { ¿Qué tipo de venta realiza? } \\
\text { Automáticas } \\
0 \%\end{array}$ & $\begin{array}{l}\text { Most sales are made directly } \\
\text { at the point of sale, the rest, } \\
\text { in a reduced form, makes } \\
\text { use of either telephones or } \\
\text { the Internet, which shows a } \\
\text { limited development of } \\
\text { sales using the resources } \\
\text { that digital technology } \\
\text { offers. }\end{array}$ \\
\hline ¿De que forma le da seguimiento a su cliente? & $\begin{array}{l}\text { As we read in the graph, } \\
\text { over a quarter of the } \\
\text { business community does } \\
\text { not follow up on their } \\
\text { clients; } 20 \% \text { do, although } \\
\text { they do not make it clear in } \\
\text { what way. Only a small part } \\
\text { uses the Internet, without } \\
\text { clarifying the medium. This } \\
\text { fundamental factor in } \\
\text { business development is not } \\
\text { considered important, } \\
\text { which could be a key factor } \\
\text { in its slow growth. }\end{array}$ \\
\hline ¿Realiza Investigaciones de Mercado? & $\begin{array}{l}\text { More than half do not carry } \\
\text { out market research, which } \\
\text { would imply that they do } \\
\text { not necessarily know } \\
\text { towards whom they are } \\
\text { directing their } \\
\text { services/products, what } \\
\text { their perception of the } \\
\text { actions implemented by the } \\
\text { company is, and they hardly } \\
\text { know their competitors, } \\
\text { among others. It is } \\
\text { necessary to make people } \\
\text { aware of the importance of } \\
\text { this marketing action. }\end{array}$ \\
\hline
\end{tabular}




\begin{tabular}{|c|c|}
\hline 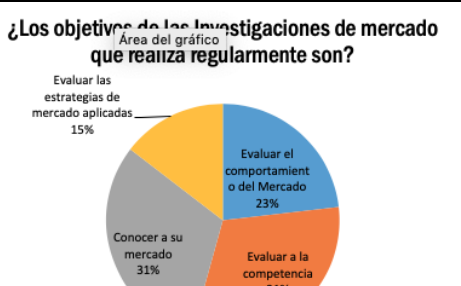 & $\begin{array}{l}\text { Of those who conduct } \\
\text { research, less than a third do } \\
\text { so to evaluate the } \\
\text { competition; another third } \\
\text { to know the market, and less } \\
\text { than a quarter to know how } \\
\text { the market moves, which } \\
\text { suggests that there is clarity } \\
\text { about the commercial scope } \\
\text { of such research. }\end{array}$ \\
\hline $\begin{array}{l}\text { ¿Su empresa cuenta con área de devoluciones, } \\
\text { atennitín al alinanton, sugerencias y garantias? } \\
\text { Titulo del gráfico }\end{array}$ & $\begin{array}{l}\text { More than half do not offer } \\
\text { guarantees or customer } \\
\text { service; the rest do. It is } \\
\text { worrisome, however, that } \\
\text { most do not consider the } \\
\text { customer-user-consumer } \\
\text { and their support as a } \\
\text { substantive in the } \\
\text { development of their } \\
\text { business. }\end{array}$ \\
\hline $\begin{array}{l}\text { ¿Cuenta con E-mail o linea telefónica que su } \\
\text { cliente conoce para contactarlo? }\end{array}$ & $\begin{array}{l}\text { It is shown that most } \\
\text { companies surveyed use } \\
\text { either email or telephone as } \\
\text { a means of contacting their } \\
\text { customers. It would be } \\
\text { necessary to evaluate the } \\
\text { incorporation of other } \\
\text { strategies, such as the use of } \\
\text { social networks to achieve a } \\
\text { greater approach to the } \\
\text { market. }\end{array}$ \\
\hline $\begin{array}{l}\text { ¿Su empresa tiene página Web? } \\
\text { Área del gráfico }\end{array}$ & $\begin{array}{l}\text { More than two thirds of the } \\
\text { companies have not } \\
\text { incorporated a web page as } \\
\text { part of their communication } \\
\text { strategies, which is a } \\
\text { significant disadvantage } \\
\text { compared to those that do } \\
\text { make use of new } \\
\text { technologies. Such } \\
\text { backwardness generates, } \\
\text { consequently, little or no } \\
\text { market share for them. }\end{array}$ \\
\hline $\begin{array}{l}\text { ¿Cuenta con algún mecanismo de interacción o } \\
\text { ligas de comunicación en su página de Intemet } \\
\text { para comunicarse con su cliente? }\end{array}$ & $\begin{array}{l}\text { As can be seen in the graph, } \\
\text { of the total number of } \\
\text { companies that do have a } \\
\text { web page, they do not, } \\
\text { however, have any effective } \\
\text { means of communication } \\
\text { with their clients; the page, } \\
\text { therefore, is only } \\
\text { informative, but does not } \\
\text { generate interaction with the } \\
\text { market. }\end{array}$ \\
\hline $\begin{array}{l}\text { ¿Las Redes Sociales que utiliza en la empresa } \\
\text { para comunicarse con su mercado son? } \\
\text { Titulo del gráfico }\end{array}$ & $\begin{array}{l}\text { Whatsapp and Facebook are } \\
\text { the social networks most } \\
\text { used by companies that have } \\
\text { contact with their market; } \\
\text { however, more than a } \\
\text { quarter do not have any, } \\
\text { which would mean a } \\
\text { significant brake on their } \\
\text { growth, considering today's } \\
\text { commercial trends. }\end{array}$ \\
\hline $\begin{array}{l}\text { ¿Cuenta con personal de adminstración en las } \\
\text { Rede! Titulo del gráfico ágina Web? }^{\text {The }}\end{array}$ & $\begin{array}{l}\text { However, companies that } \\
\text { use some kind of social } \\
\text { network do not have } \\
\text { someone to manage and } \\
\text { maintain them. They may } \\
\text { not be using them optimally, } \\
\text { or they may not be paying as } \\
\text { much attention to them. }\end{array}$ \\
\hline
\end{tabular}

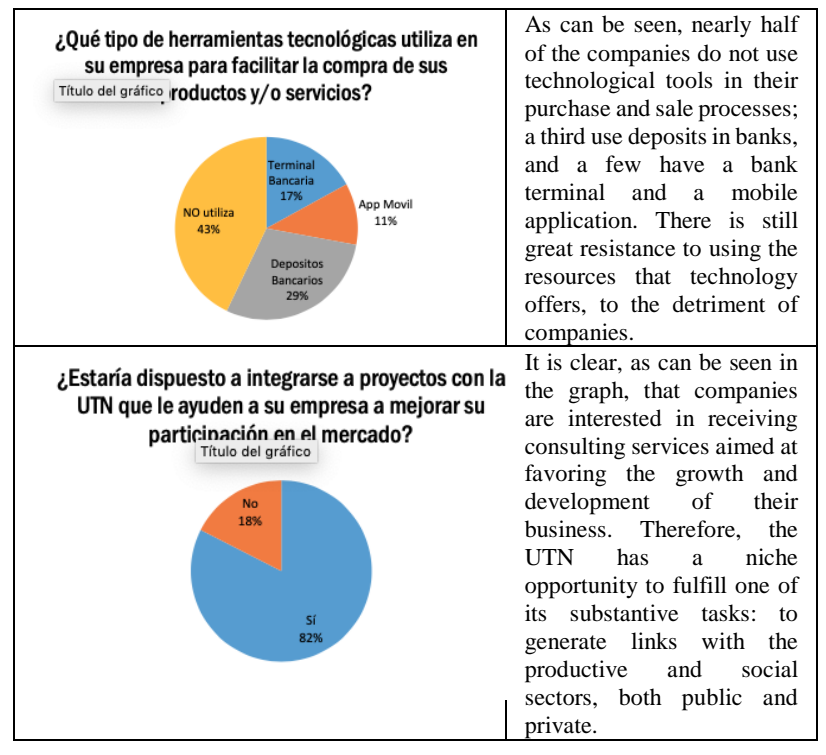

\section{Results}

Based on the information generated, the following results can be assumed, most of which can be inferred, such as the problems presented by the companies in the municipality of Nezahualcóyotl, which can become an area of opportunity for them:

The total number of companies in Nezahualcóyotl, according to the services and goods they offer, are divided into the following categories:

a) Prepared meals (24.7\%)

b) Sale of personal use products (11.6\%)

c) Educational services $(4.7 \%)$

d) Sale of household supplies (stationery and miscellaneous stores) (35.7\%)

e) Sale of various products for different uses $(7.3 \%)$

f) Business support services (consultancy, advertising and advisory services and sale of technology) (16\%)

- $\quad$ Most of the companies are micro, they come from family structures and do not exceed 10 employees. Nevertheless, they generate an important income, and strictly speaking, because of their number, they give life to the economy of the municipality.

As a micro, the vast majority of enterprises suffer from a perception of their own business, of an organization as such, and in very few cases they use the resources that marketing and the digital era offer. 
- Their development could be less than their growth, that is to say, although they generate important sales, in the organizational part it goes down the drain, since there is no base that sustains them, hence the risk of falling is always latent.

- $\quad$ There is a permanent emergence of micro and small enterprises, many of which offer goods and services already in existence, which represents greater competitiveness and that diminishes their ability to remain in the market, even more so with the limited or no use of marketing and/or technological strategies.

- $\quad$ The few enterprises that apply marketing and commercial communication resources using technologies do so in a limited and self-learning way. Although they do not express it directly, the lack of application of marketing resources is a consequence of investment, since they assume that they represent unnecessary expenses.

- $\quad$ Finally, the resulting information shows that, although there may be resistance to change and to the application of market resources, the majority are inclined to experiment with what the UTN, through its collegiate bodies and its linkage area, can offer them. This implies the opening of a very important niche of opportunity, since it would allow this educational institution to reaffirm the necessary and important link with the productive sectors, especially the private ones, for the benefit of the community, since they give rise to economic growth, the generation of jobs and the development of the whole region.

\section{Suggestions}

According to the results obtained, most of the companies are micro, so we would like to present a series of suggestions that could give light and viability. They revolve around the marketing and use of the technologies that the globalized and competitive world offers.
The University, as a decentralized public organization of the government of the State of Mexico, has imposed itself, in addition to its substantive tasks of quality education and excellence, research and extension of culture, to maintain links with the productive sectors, because just from its classrooms and laboratories, emerges the human talent that such sectors need, and with their knowledge and skills base the development of enterprises. Likewise, through its Academic Bodies -collegiate and multidisciplinary knowledge organizations- and their projects, they provide answers to the problems presented by social and productive entities. Thus, responding to this complex business reality in the municipal and regional context has two main responses.

In order to address this problem, the Academic Body for New Technologies and MSMEs develops projects aimed at enriching the processes and technologies that promote development and growth, with particular attention to MSMEs.

According to the results obtained, and with the contextual information of the business reality in this region of the eastern part of the State of Mexico, it is suggested:

1. Networking with the presence of entrepreneurs, managers and researchers from Nezahualcóyotl.

2. Recovering, in terms of minutes or reports, what was said in the event.

3. Based on this information, schedule meetings called "INTRODUCTION TO THE USE OF MARKET AND TECHNOLOGICAL RESOURCES FOR THE DEVELOPMENT OF NEZAHUALCÓYOTL MSMEs".

4. Determining the delivery of courses and workshops with the following subjects:
a. Business Plan Development (Environment Analysis).
b. Development and application of technological resources in business training.
c. Development and application of marketing strategies.
d. Development and use of business applications.
e. Knowledge and use of digital strategies (Social Media) 


\section{Conclusion}

The current commercial dynamic undoubtedly requires substantial changes on the part of companies, and MSMEs cannot escape this necessary transformation, especially considering that today any company, of any size, can be seen at a global level. Therefore, it is essential to identify the shortcomings in the organization that may hinder this transformation, in order to compete on equal terms in the market.

The work carried out in this project can be the beginning of well-directed efforts for the MSMEs in the east of the State of Mexico and, in collaboration with institutions in the area whose raison d'être is to train and educate citizens, can contribute to the development and growth of the country and increase the opportunities for companies and citizens.

The information shown in this work could be the basis for decision making of businessmen in the area, thus having elements to choose the best alternatives of action.

And for the UTN, it will represent an area of opportunity to project, link and promote the potential of graduates from different majors within the same municipality.

\section{References}

(https://www.dgcs.unam.mx/boletin/bdboletin/2 014_471.html)

Anzola, R. S. ADMINISTRACIÓN DE PEQUEÑAS EMPRESAS. McCraw Hills, Mexico, 2006

$\begin{array}{lrrr}\text { Fernández, } & \text { Ricardo } & \text { MANUAL } & \text { PARA } \\ \text { ELABORAR } & \text { UN } & \text { PLAN } & \text { DE }\end{array}$ MERCADOTECNIA. MCGrw-Hill, Mexico, 2007

Gariblay, Jazmín. ¿CUÁL ES LA DIFERENCIA ENTRE UNA MICRO EMPRESA Y UNA PEQUEÑA? Merca 2.0, Mexico, 2016

https://www.inegi.org.mx/app/mapa/denue

Linares Zarco, Jaime. CIUDAD NEZAHUALCÓYOTL, DE LA POBREZA A LA GLOBALIZACIÓN ECONÓMICA Y LA SATURACIÓN URBANA. 